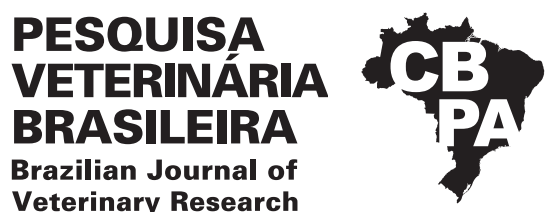

\title{
mcr-1-carrying Enterobacteriaceae isolated from companion animals in Brazil ${ }^{1}$
}

\author{
Vanessa C. Kobs*2 (D), Rafael E. Valdez ${ }^{3}$ (D), Francielle de Medeiros ${ }^{4}$ (D), \\ Patrícia P. Fernandes ${ }^{4}$ (D), Roseneide C. Deglmann² (D), Regina M.M. Gern² (D) \\ and Paulo H.C. França ${ }^{2}$ (D)
}

\begin{abstract}
Kobs V.C., Valdez R.E., Medeiros F., Fernandes P.P., Deglmann R.C., Gern R.M.M. \& França P.H.C. 2020. $\mathbf{m c r}$-1-carrying Enterobacteriaceae isolated from companion animals in Brazil. Pesquisa Veterinária Brasileira 40(9):690-695. Laboratório de Microbiologia e Biologia Molecular, Universidade da Região de Joinville, Rua Paulo Malschitzki 10, Zona Industrial Norte, Joinville, SC 89219-710, Brazil. E-mail: v.kobs@univille.br

Plasmid-mediated polymyxin resistance was first described in 2015, in China, in Escherichia coli carrying the mcr-1 (Mobile Colistin Resistance-1) gene. Since then, it has become a major public health challenge worldwide, representing a major threat to human and animal health. In addition, there are still few reports on the prevalence of $m c r-1$ in Enterobacteriaceae isolated from humans, animals and food. Therefore, the purpose of the study was to investigate the occurrence of the $m c r-1$ gene in bacterial isolates with phenotypic resistance to polymyxin B obtained from clinical specimens of companion animals. Phenotypic resistance to polymyxin B were determined by broth microdilution and the susceptibility profile to other antimicrobials (amikacin, amoxicillin/clavulanate, ampicillin, ampicillin/ sulbactam, aztreonam, cefazolin, cefepime, cefotaxime, cefoxitin, ceftazidime, ceftriaxone, chloramphenicol, ciprofloxacin, doxycycline, ertapenem, gentamicin, imipenem, marbofloxacin, meropenem, phosphomycin, piperacillin/tazobactam, tetracycline, ticarcillin/clavulanate, tobramycin and trimethoprim/sulfamethoxazole) by disc-diffusion agar method. The extraction of bacterial DNA was performed via heat shock followed by spectrophotometric evaluation. To verify the presence of $m c r-1$, the Polymerase Chain Reaction was employed using specific primers, followed by agarose gel electrophoresis. The positive isolates had the corresponding amplicons sequenced. In this study, there were identified the first isolates of Escherichia coli, Klebsiella spp. and Enterobacter spp. carrying the $m c r-1$ gene derived from specimens of companion animals in Brazil. Our results suggest the dissemination of resistance to polymyxins in the community and the environment, highlighting the need for surveillance and optimized treatment guidelines.
\end{abstract}

INDEX TERMS: $m c r$-1-carrying Enterobacteriaceae, companion animals, Brazil, bacterium, polymyxin B, multiple drug resistance, MDR genes, $m c r-1$ gene.

\footnotetext{
RESUMO.- [Enterobacteriaceae portadora de $m c r-1$ em isolados clínicos de animais de companhia: primeiro relato no Brasil.] A resistência à polimixina mediada por plasmídeo teve sua primeira descrição em 2015, na China, em Escherichia coli portadora do gene mcr-1 (Mobile Colistin Resistance-1) e a partir de então tornou-se um grande

${ }^{1}$ Received on May 18, 2020.

Accepted for publication on June 1, 2020.

${ }^{2}$ Graduate Program in Health and Environment, Laboratório de Microbiologia e Biologia Molecular, Universidade da Região de Joinville (Univille), Rua Paulo Malschitzki 10, Zona Industrial Norte, Joinville, SC 89219-710, Brazil. *Corresponding author: v.kobs@univille.br
}

desafio para a saúde pública em todo o mundo, constituindo uma grande ameaça à saúde humana e animal. Além disso, ainda existem poucos relatos sobre a prevalência de $\mathrm{mcr}-1$ em Enterobacteriaceae isoladas de humanos, animais e alimentos. Sendo assim, o objetivo do estudo foi investigar a ocorrência do gene $m c r-1$ em isolados bacterianos com

\footnotetext{
${ }^{3}$ Departamento de Ciências Biológicas, Universidade da Região de Joinville (Univille), Rua Paulo Malschitzki 10, Zona Industrial Norte, Joinville, SC 89219-710, Brazil.

${ }^{4}$ Laboratório Medivet Diagnósticos Veterinários, Rua Presidente Campos Sales 214, Glória, Joinville, SC 89217-100, Brazil.
} 
resistência fenotípica à polimixina $\mathrm{B}$, oriundos de materiais clínicos de animais de companhia. A resistência fenotípica à polimixina B foi determinada por microdiluição em caldo e o perfil de sensibilidade aos demais antimicrobianos (amicacina, amoxicilina/clavulanato, ampicilina, ampicilina/sulbactam, aztreonam, cefazolina, cefepime, cefotaxima, cefoxitina, ceftazidima, ceftriaxona, cloranfenicol, ciprofloxacina, doxiciclina, ertapenem, gentamicina, imipinem, marbofloxacino, meropenem, fosfomicina, piperacilina/tazobactam, tetraciclina, ticarcilina/ clavulanato, tobramicina sulfametoxazol/trimetoprim) foram determinados pelo método disco difusão. A extração do DNA bacteriano foi realizada via choque térmico, seguido de avaliação espectrofotométrica. Para a verificação da presença do $m c r-1$ foi utilizada a Reação em Cadeia da Polimerase com emprego de iniciadores específicos, seguida de eletroforese em gel de agarose. Os isolados positivos tiveram os correspondentes amplicons sequenciados. Nesse estudo foram identificados os primeiros isolados de Escherichia coli, Klebsiella spp. e Enterobacter spp. portadores do gene $\mathrm{mcr}$ - 1 derivados de espécimes de animais de companhia no Brasil. Este estudo sugere a disseminação da resistência às polimixinas na comunidade e no meio ambiente, destacando a necessidade de vigilância e diretrizes otimizadas de tratamento.

TERMOS DE INDEXAÇÃO: Enterobacteriaceae portadora de $m c r-1$, animais de companhia, Brasil, bactérias, polimixina B, resistência a múltiplos medicamentos, genes MDR, gene mor-1.

\section{INTRODUCTION}

The emergence and rapid spread of resistant microorganisms is considered one of the most relevant and challenging public health problems worldwide, both for human health and for veterinary medicine, as it imposes clinical, social and economic consequences (Liu et al. 2016). On a global scale, 700,000 people die each year from infections by antimicrobial-resistant bacteria. It is estimated that these deaths could reach 10 million by 2050 , which would exceed the deaths attributed to cancer, now considered the largest cause of death in the world (8.2 million deaths per year) (ANVISA 2017).

In particular, infections caused by multidrug-resistant (MDR) bacteria of the Enterobacteriaceae family have become a major concern due to significant limitations on therapeutic options. As a consequence, there was an increase in the use of colistin, a cationic peptide antibiotic from the polymyxin family considered one of the last effective drugs for the treatment of infections by Gram-negative bacterium resistant to carbapenem antimicrobials (Eiamphungporn et al. 2018). The delicate balance between the clinical need and the prevention of resistance emergence has been further compromised by the agricultural use of some human antimicrobials, being widely recognized that some countries have actively used colistin in farm animals, favoring the development of resistance and its dissemination to the environment (Liu et al. 2016).

Until recently, it was considered that the acquired resistance to polymyxins was limited to the occurrence of chromosomal mutations, essentially non-transferable (McEwen \& Collignon 2018). However, in 2015, Liu et al. (2016) reported the occurrence of the first plasmid-mediated mechanism of resistance to polymyxins ( $m c r-1$ gene) in Escherichia coli isolates in China. On the other hand, in 2018, Wang et al. (2018) reported the occurrence of isolates of different bacterial species carrying the mcr-1 gene in 31 countries, having China the highest number of reported cases, suggesting that the indiscriminate use of antimicrobials in Chinese agriculture, especially colistin, has caused the initial dissemination of the gene. In addition, other studies have shown that the reservoirs of such bacteria are increasing, not only in agriculture, but also in wild animals and the environment. In 2017, Sellera et al. (2017) reported for the first time the occurrence of the $\mathrm{mcr}$ - 1 gene in migratory penguins of the species Spheniscus magellanicus. In the same year, Fernandes et al. (2017) collected water samples from beaches in São Paulo State, Brazil, and reported the presence of international clones of $E$. coli carrying the $m c r-1$ gene. Notoriously, dogs and cats also represent a possible source for the diffusion of resistance due to the indiscriminate use of antimicrobial agents in the veterinary routine and the close contact of these animals with humans. As suggested by Zhang et al. (2016) in an analysis of clonal relationships conducted in China, dissemination can also occur in pets and veterinary clinics.

Considering the accumulated data, the World Health Organization evidenced the threat to human health facing colonization and infection by bacteria carrying $m c r-1$ associated with other genes encoding extended-spectrum beta-lactamases and carbapenemases in a single plasmid (Dalmolin et al. 2018). Given this world scenario, researchers emphasize that, among other actions, conducting epidemiological and molecular studies on the distribution and dissemination of the $m c r-1$ gene is extremely important to protect the efficiency of the drug colistin (Liu et al. 2016). Therefore, after extensive consultation in the scientific literature on the occurrence of bacteria carrying $m c r-1$ isolated from animals, it was found a scarce number of publications addressing companion animals, including the lack of data generated in Brazil. Thus, this study aimed to investigate the occurrence of the $\mathrm{mcr}$-1 gene in bacteria resistant to polymyxin $\mathrm{B}$, isolated from clinical specimens of companion animals.

\section{MATERIALS AND METHODS}

Selection of clinical isolates. There were considered bacterial isolates from companion animals (dogs and cats) with resistance to polymyxin B by phenotypic screening method (Kirby-Bauer discdiffusion) (Galani et al. 2008), identified during routine microbiological investigation from February 2017 to August 2018, together with characterizing data from the host animal and clinical specimens.

Evaluation of the antimicrobial susceptibility profile. The determination of the phenotypic profile of susceptibility to antimicrobials was performed by the Kirby-Bauer disc-diffusion test (Bauer et al. 1966). Antimicrobials recommended by the Clinical and Laboratory Standards Institute (CLSI) of the current year were employed and individually categorized for each veterinary species. In addition, in $m c r$-1-positive isolates, other antimicrobial groups were tested to define the bacterium profile as Multidrug-resistant (MDR), Extensively drug-resistant (XDR) and Pandrug-resistant (PDR), as recommended by Magiorakos et al. (2012). All discs used came from the same manufacturer (Cefar, São Paulo, Brazil). The phenotypic susceptibility to polymyxin B of isolates carrying the $\mathrm{mcr}-1$ gene was confirmed by broth microdilution to obtain the minimum inhibitory concentration (MIC), as instructed by the manufacturer of the "Policimbac" kit (Probac, Sao Paulo, Brazil).

The results were interpreted according to the CLSI guidelines of the current year, except for polymyxin B, which followed the criteria 
of the European Committee on Antimicrobial Susceptibility Testing (EUCAST) for broth microdilution, with isolates showing MIC $>2 \mu \mathrm{g}$ / $\mathrm{mL}$ being considered resistant.

mcr-1 gene investigation. All bacterial isolates were processed by molecular analyzes. The extraction of bacterial DNA was performed via heat shock from solid medium culture (Vaneechoutte et al. 1995). In the end, the supernatant containing the bacterial DNA was evaluated by spectrophotometry (readings at 260 and 280nm) in an Epoch (BioTek Instruments, Winooski, USA) device and stored at $-20^{\circ} \mathrm{C}$. The presence of the $m c r-1$ gene was evaluated by Polymerase Chain Reaction (PCR), using the XP Cycler (Bioer Technology Co, Hangzhou, China) and the pair of primers CLR5-F (5'CGGTCAGTCCGTTTGTTC'3) and CLR5-R (5'CTTGGTCGTCTGTAGGGG'3), which provides the amplification of a specific segment of $309 \mathrm{bp}$ of the gene (Liu et al. 2016). The thermal cycling used was composed of an initial denaturation step at $94^{\circ} \mathrm{C}$ for $3 \mathrm{~min}$, followed by 40 cycles of $94^{\circ} \mathrm{C}$ for $30 \mathrm{~s}, 61.5^{\circ} \mathrm{C}$ for $1 \mathrm{~min}$ and $72^{\circ} \mathrm{C}$ for $30 \mathrm{~s}$, besides the final extension at $72^{\circ} \mathrm{C}$ for $10 \mathrm{~min}$. The PCR products were confirmed via electrophoresis in 1\% agarose gel, followed by digitized recording (MiniBis-Pro Photodocumentation System, DNR Bio-Image Systems Ltd., Jerusalem, Israel). The standard strain (positive control for $m c r-1$ ), E. coli RM 12983, was kindly provided by Dr. Marcelo Pilonetto, "Laboratório Central do Estado do Paraná” (LACEN-PR), Curitiba, Brazil.

The $m c r$-1-positive amplicons were submitted to direct bidirectional sequencing using the Big Dye ${ }^{\circledR}$ Terminator v3.1 kit on the ABI-Prism 3500 Genetic Analyzer platform (Applied Biosystems, Carlsbad, USA) and compared to the reference nucleotide sequences of $m c r-1$ (GeneBank accession no. KP347127), $m c r-1.2$ (NG051170), mcr-1.3 (NG052861), mcr-1.4 (KY041856), mcr-1.5 (KY283125), mcr-1.6 (NG052893), mcr-1.7 (KY488488), mcr-1.8 (KY683842), mcr-1.9 (KY780959), mcr-2 (NG051171), mcr-3 (KY924928), mcr-4 (NG057470), mcr-5 (MG241339), mcr-6 (MF176240), mcr-7 (NG056413) and mcr-8 (NG061399) genes employing the ClustalW software available in the BioEdit package version 7.2.6.1.

\section{RESULTS}

There were identified a total of 64 bacterial isolates with phenotypic resistance to polymyxin B derived from 62 dogs (20 males and 42 females) and 2 cats ( 1 male and 1 female) in the initial screening. The species corresponding to the identified isolates are distributed according to the type of specimens in Table 1.

Bacteria with non-intrinsic resistance to polymyxins most frequently found were Escherichia coli (27), Enterobacter spp. (7), Pseudomonas spp. (7) and Klebsiella spp. (6). The genus Proteus was frequently isolated (17); however, it has intrinsic resistance mechanisms.

Among all investigated ones, 3 (4.7\%) bacterial isolates, all derived from dogs, were positive for the $m c r-1$ gene, as identified by PCR and confirmed via sequencing, specifically present in E. coli (urine isolate), Enterobacter spp. (nasal secretion isolate) and Klebsiella spp. (isolate of abdominal seroma).

The results of the MIC determination to polymyxin B of the positive isolates for the $m c r-1$ gene and the phenotypic evaluation against the antimicrobials tested in these isolates are presented in Table 2. All $\mathrm{mcr}$-1-positive isolates were MDR.

\section{DISCUSSION}

To date, the occurrence in Brazil of the mcr-1 gene in Escherichia coli has been described in clinical isolates of human patients (Fernandes et al. 2016a, Rossi et al. 2017) and in samples from the retail trade of pork and chickens (Fernandes et al. 2016b). In addition, in Klebsiella pneumoniae, the presence of $m c r-1$ was reported in high-risk strains concomitantly carrying $b l a_{\mathrm{KPC}-2}$, also derived from human clinical specimens (Dalmolin et al. 2018). In the present study, the first clinical isolates carrying the mcr-1 gene in E. coli, Klebsiella spp. and Enterobacter spp., derived from clinical specimens of companion animals, are reported in Brazil.

Although data on the epidemiology of the $m c r-1$ gene in veterinary medicine are still relatively scarce, other studies have reported the detection of polymyxin-resistant $\mathrm{mcr}-1$ positive isolates from companion animals. Lei et al. (2017), in a study conducted in China, reported the presence of $E$. coli, K. pneumoniae and E. aerogenes carrying $m c r-1$ isolated from companion animals and their respective owners. It was demonstrated that the bacterial isolate from one of the owners presented the same genetic group as 5 isolates from dogs and cats, highlighting the possible transmission of strains carrying this gene between animals and contacting humans. In another study, carried out in Ecuador by Loayza et al. (2018), the presence of $E$. coli carrying the $m c r-1$ gene was demonstrated in companion animals sharing the same environment as a child with peritoneal infection by $\mathrm{mcr}$-1positive $E$. coli, suggesting a clonal dissemination, since the detected $m c r-1$ gene belonged to the same plasmid in all isolates. In view of the aforementioned, it is observed that the presence of the gene in strains isolated from companion animals can be a natural reservoir, introducing another complex form of dissemination in the community (McEwen \& Collignon 2018).

The identification of strains carrying the $m c r-1$ gene with MIC indicative of susceptibility to polymyxin B, as observed in most cases of this study, points that the potential for manifestation of resistance provided by $\mathrm{mcr}-1$ may be difficult to define exclusively based on phenotypic tests. This aspect can contribute to the silent dissemination of strains carrying this resistance mechanism, considering that the tests to verify

Table 1. Distribution of bacterial isolates of companion animals with phenotypic resistance to polymyxin $B$ in different clinical specimens

\begin{tabular}{|c|c|c|}
\hline $\begin{array}{c}\text { Clinical } \\
\text { specimens }\end{array}$ & $\begin{array}{l}\text { Isolates } \\
\text { (n) }\end{array}$ & Bacterial identification \\
\hline Urine & 50 & $\begin{array}{l}\text { Escherichia coli (25), Proteus spp. (15), } \\
\text { Enterobacter spp. (4), Klebsiella spp. (4) } \\
\text { and Pseudomonas spp. (2) }\end{array}$ \\
\hline $\begin{array}{l}\text { Otological } \\
\text { secretion }\end{array}$ & 7 & $\begin{array}{l}\text { Pseudomonas spp. (4), Enterobacter } \\
\text { spp. (1), Escherichia coli (1) and } \\
\text { Proteus spp. (1) }\end{array}$ \\
\hline Nasal secretion & 3 & $\begin{array}{l}\text { Enterobacter spp. (1), Klebsiella spp. (1) } \\
\text { and Pseudomonas spp. (1) }\end{array}$ \\
\hline Skin swab & 1 & Enterobacter spp. \\
\hline Interdigital swab & 1 & Proteus spp. \\
\hline $\begin{array}{l}\text { Abdominal } \\
\text { seroma swab }\end{array}$ & 1 & Klebsiella spp. \\
\hline Unidentified & 1 & Escherichia coli \\
\hline
\end{tabular}


the presence or absence of $m c r-1$ are generally performed only in isolates with phenotypic resistance previously defined via disc-diffusion (Fernandes et al. 2016b). In fact, in a study conducted in the Netherlands based on specimens from human patients admitted to a tertiary hospital, Terveer et al. (2017) reported E. coli carrying the $m c r-1$ gene, but susceptible to colistin (MIC $=0.25 \mu \mathrm{g} / \mathrm{mL}$ ). Although the complete genome analysis showed the nucleotide sequence of the $\mathrm{mcr}$ - 1 gene found in this isolate was $100 \%$ homologous to the first sequence published of the gene, the open reading frame had been interrupted by a long insertion sequence (IS10R) of 1329 bp in the transposon of the $m c r-1$ gene, which was probably responsible for the behavior of phenotypic susceptibility to colistin. In this sense, we cannot exclude the possibility that an equivalent phenomenon may also have occurred in the isolates described in our manuscript. In a study with clinical isolates of human patients from five cities in Brazil, Pillonetto et al. (2019) also reported E.coli carrying $\mathrm{mcr}-1$ exhibiting low MIC values for polymyxin B $(\leq 2 \mu \mathrm{g} / \mathrm{mL})$, corroborating with the hypothesis that bacteria carrying this gene may not usually be detected and continue extending the dissemination among humans, animals and the environment.

Colistin and polymyxin B belong to the class of polymyxins, a class of antimicrobials that had its use almost suspended in the 1970s due to its high toxicity rate. In recent years, its use was reintroduced as a last resource for the treatment of infections caused by Gram-negative bacilli resistant to all other commercially available classes of drugs (McEwen \& Collignon 2018). However, some mechanisms of resistance to polymyxins have already been documented, such as efflux pumps, thickening of the polysaccharide capsule, changes in the concentrations of membrane-specific proteins and, mainly, changes in the structure of the external membrane, particularly the lipopolysaccharide (LPS), modulated by two chromosomally coded regulatory components - PmrAB and PhoPQ (Eiamphungporn et al. 2018). Changes in these regulation systems cause a cationic substitution of the LPS target by the addition of positively charged molecules of 4-amino-4-deoxyL-arabinosis (L-ara4N) and/or phosphoethanolamine (PEtN). Thus, the ionic pattern of the external membrane is modified

Table 2. List of $\mathbf{m c r}$-1-positive isolates with corresponding minimum inhibitory concentration for polymyxin B and antimicrobial susceptibility profile

\begin{tabular}{|c|c|c|c|c|}
\hline \multicolumn{5}{|c|}{ Phenotypic evaluation of antimicrobial susceptibility (Kirby-Bauer method) ${ }^{a}$} \\
\hline Group & \multicolumn{2}{|l|}{ Antimicrobial } & \multicolumn{2}{|l|}{ Interpretation } \\
\hline Phosphonic acid & Phosphomycin & S & S & S \\
\hline Aphenicols & Chloramphenicol & S & S & S \\
\hline \multirow{2}{*}{ Aminoglycosides } & Tobramicin & S & S & S \\
\hline & Amikacin & S & S & S \\
\hline$\beta$-lactams with Inhibitors & Ticarcillin/Clavulanate & $\mathrm{R}$ & $\mathrm{R}$ & $\mathrm{R}$ \\
\hline \multirow[t]{3}{*}{ Carbapenems } & Meropenem & S & S & S \\
\hline & Ertapenem & S & S & S \\
\hline & Imipenem & S & S & S \\
\hline \multirow{2}{*}{$\begin{array}{l}\text { Cephalosporins - 1st and 2nd } \\
\text { generation (not broad spectrum) }\end{array}$} & Cefazolin & $\mathrm{R}$ & $\mathrm{R}$ & S \\
\hline & Cefazolin (urinary) & S & $\mathrm{R}$ & S \\
\hline $\begin{array}{l}\text { Broad spectrum Cephalosporins - } \\
\text { 3rd and 4th generation }\end{array}$ & Cefotaxime Ceftriaxone & $\mathrm{R}$ & $\mathrm{R}$ & S \\
\hline \multirow[t]{2}{*}{ Fluoroquinolones } & Ciprofloxacin & $\mathrm{R}$ & $\mathrm{R}$ & $\mathrm{R}$ \\
\hline & Marbofloxacin & $\mathrm{R}$ & $\mathrm{R}$ & S \\
\hline Folate synthesis inhibitors & Sulfa/Trimethoprim & $\mathrm{R}$ & S & S \\
\hline Monobactamic & Aztreonam & S & S & S \\
\hline Penicillin & Ampicillin & $\mathrm{R}$ & $\mathrm{R}$ & $\mathrm{R}$ \\
\hline \multirow[t]{2}{*}{ Penicillin $+\beta$ - lactamase inhibitors } & Amoxicillin+Clavulanate & S & S & S \\
\hline & Ampicillin+Sulbactam & S & S & S \\
\hline Polymyxins ${ }^{b}$ & Polymyxin B & $\mathrm{R}$ & $\mathrm{R}$ & $\mathrm{R}$ \\
\hline \multirow[t]{2}{*}{ Tetracyclines } & Tetracycline & $\mathrm{R}$ & $\mathrm{R}$ & S \\
\hline & Doxycycline & $\mathrm{R}$ & $\mathrm{R}$ & S \\
\hline
\end{tabular}

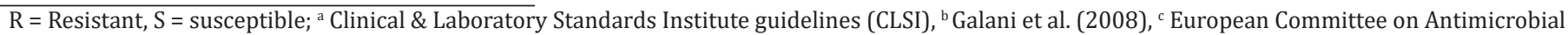
Susceptibility Testing (EUCAST), ${ }^{d}$ Magiorakos et al. (2012). 
and the total anionic load is decreased, affecting the electronic interaction of LPS with polymyxin molecules, reducing their affinity (Eiamphungporn et al. 2018). The acquisition of the plasmid-mediated $\mathrm{mcr}$-1 gene, the newest reported mechanism of resistance (Liu et al. 2016), allows the synthesis of an enzyme from the phosphoethanolamine transferase family. When expressed, it adds a phosphoethanolamine residue to lipid A, which is the portion that anchors LPS on the surface of the external membrane, resulting in a resistance mechanism very similar to the mediated by chromosomal modulations (Eiamphungporn et al. 2018).

In this study, from the isolates without intrinsic resistance to polymyxins, only 3 were confirmed as $m c r-1$ gene carriers; therefore, 44 isolates should have other mechanisms not investigated, creating an additional difficulty to the predictability of the dissemination of resistance to polymyxins. However, all $m c r$-1-positive isolates were MDR, confirming the concern for human health in the face of colonization and infection by such bacteria, especially when other resistance genes occur concomitantly in the same organism, due to the great therapeutic limitation (Magiorakos et al. 2012).

\section{CONCLUSIONS}

In this study, there were identified the first isolates carrying the $m c r-1$ gene derived from clinical specimens of companion animals in Brazil. This fact increases the concern about antimicrobial resistance in human and veterinary medicine, due to the close contact of companion animals with humans.

The need to improve the control of the use of polymyxins in veterinary medicine, livestock and human medicine is highlighted, in order to hinder the dissemination of resistance to other bacterial species in the community, environment and hospital facilities, as well as to prevent the association of the mcr-1 gene to other markers of resistance in the same strains.

Acknowledgements.- We would like to thank the staff at "Laboratório de Microbiologia e Biologia Molecular" of Univille and "Laboratório Medivet Diagnósticos Veterinários" that provided technical support for the development of this study. This study was funded by the Research Support Fund of the "Universidade da Região de Joinville" (FAP-Univille).

Conflicts of interest statement.- There are no conflicts of interest in relation to the data presented.

\section{REFERENCES}

ANVISA 2017. Plano de Ação da Vigilância Sanitária em Resistência aos Antimicrobianos. Agência Nacional de Vigilância Sanitária, Brasília, DF, p.1-50.

Bauer A.W., Kirby W.M., Sherris J.C. \& Turk M. 1966. Antibiotic susceptibility testing by a standarized single disk method. Am. J. Clin. Pathol. 45(4):493-496. <PMid:5325707>

Dalmolin T.V., Martins A.F., Zavascki A.P., Lima-Morales D. \&, Barth A.L. 2018. Acquisition of the $m c r-1$ gene by a high-risk clone of KPC-2-producing Klebsiella pneumoniae ST437/CC258, Brazil. Diagn. Microbiol. Infect. Dis. 90(2):132-133.<http://dx.doi.org/10.1016/j.diagmicrobio.2017.09.016> $<$ PMid:29169659>

Eiamphungporn W., Yainoy S., Jumderm C., Tan-arsuwongkul R., Tiengrim S. \& Thamlikitkul V. 2018. Prevalence of the colistin resistance gene $\mathrm{mcr}-1$ in colistin-resistant Escherichia coli and Klebsiella pneumoniae isolated from humans in Thailand. J. Glob. Antimicrob. Resist. 15:32-35. <http://dx.doi. org/10.1016/j.jgar.2018.06.007> <PMid:29935331>
Fernandes M.R., McCulloch J.A., Vianello M.A., Moura Q., Pérez-Chaparro P.J., Esposito F., Sartori L., Dropa M., Matté M.H., Lira D.P.A., Mamizuka E.M. \& Lincopan N. 2016a. First report of the globally disseminated IncX4 plasmid carrying the $m c r-1$ gene in a colistin-resistant Escherichia coli ST101 isolated from a human infection in Brazil. Antimicrob. Agents Chemother. 60(10):6415-6417.<http://dx.doi.org/10.1128/AAC.01325-16> <PMid:27503650>

Fernandes M.R., Moura Q., Sartori L, Silva K.C., Cunha M.P., Esposito F., Lopes R., Otutumi L.K., Gonçalves D.D., Dropa M., Matté M.H., Monte D.F., Landgraf M., Francisco G.R., Bueno M.F., Oliveira G.D., Knöbl T., Moreno A.M. \& Lincopan N. 2016b. Silent dissemination of colistin-resistant Escherichia coli in South America could contribute to the global spread of the $\mathrm{mcr}-1$ gene. Eurosurveillance. 21(17):1-6. <http://dx.doi.org/10.2807/15607917.ES.2016.21.17.30214><PMid:27168587>

Fernandes M.R., Sellera F.P., Esposito F., Sabino C.P., Cerdeira L. \& Lincopan N. 2017. Colistin-resistant $m c r-1$-positive Escherichia coli on public beaches, an infectious threat emerging in recreational waters. Antimicrob. Agents Chemother. 61(7):e00234-17. <http://dx.doi.org/10.1128/AAC.00234-17> <PMid:28416556>

Galani I., Kontopidou F., Souli M., Rekatsina P.D., Koratzanis E., Deliolanis J. \& Giamarellou H. 2008. Colistin susceptibility testing by Etest and disk diffusion methods. Int. J. Antimicrob. Agents 31(5):434-439.<http://dx.doi. org/10.1016/j.ijantimicag.2008.01.011><PMid:18328674>

Lei L., Wang Y., Schwarz S., Walsh T.R., Ou Y., Wu Y., Li M. \& Shen Z. 2017. $m c r-1$ in Enterobacteriaceae from companion animals, Beijing, China, 2012-2016. Emerg. Infect. Dis. 23(4):710-711.<http://dx.doi.org/10.3201/ eid2304.161732><PMid:28322714>

Liu Y.Y., Wang Y., Walsh T.R., Yi L.X., Zhang R., Spencer J., Doi Y., Tian G., Dong B., Huang X., Yu L.F., Gu D., Ren H., Chen X., Lv L., He D., Zhou H., Liang Z., Liu J.H. \& Shen J. 2016. Emergence of plasmid-mediated colistin resistance mechanism mcr-1 in animals and human beings in China: a microbiological and molecular biological study. Lancet Infect. Dis. 16(2):161-168. <http://dx.doi.org/10.1016/S1473-3099(15)00424-7><PMid:26603172>

Loayza M.F., Salinas L., Villavivencio F., Rafael T., Salas S., Rivera R., Villacis J., Satan C., Ushiña L., Muñoz O., Zurita J., Melano R.G., Tijet N., Reyes J. \& Trueba G. 2018. Diverse Escherichia coli lineages, from domestic animals and humans in a household, carry colistin resistance gene $m c r-1$ in Ecuador. bioRxiv 35:1-16. <http://dx.doi.org/10.1101/350587>

Magiorakos A.P., Srinivasan A., Carey R.B., Carmeli Y., Falagas M.E., Giske C.G., Harbarth S., Hindler J.F., Kahlmeter G., Olsson-Liljequist B., Paterson D.L., Rice L.B., Stelling J., Struelens M.J., Vatopoulos A., Weber J.T. \& Monnet D.L. 2012. Multidrug-resistant, extensively drug-resistant and pandrugresistant bacteria: an international expert proposal for interim standard definitions for acquired resistance. Clin. Microbiol. Infect. 18(3):268-281. <http://dx.doi.org/10.1111/j.1469-0691.2011.03570.x><PMid:21793988>

McEwen S.A. \& Collignon P.J. 2018. Antimicrobial resistance: a one health perspective. Microbiol. Spectr. 6(2):1-26. <http://dx.doi.org/10.1128/ microbiolspec.ARBA-0009-2017><PMid:29600770>

Pillonetto M., Mazzetti A., Becker G.N., Siebra C.A., Arend L.N.V. \& Barth A.L. 2019. Low level of polymyxin resistance among $m c r-1$ positive Escherichia coli from human source in Brazil. Diagn. Microbiol. Infect. Dis. 93(2):140-142. <http://dx.doi.org/10.1016/j.diagmicrobio.2018.08.009><PMid:30355469>

Rossi F., Girardello R., Morais C., Cury A., Martins L., Silva A., Abdala E., Setubal J. \& Duarte A. 2017. Plasmid-mediated $\mathrm{mcr}-1$ in carbapenem-susceptible Escherichia coli ST156 causing a blood infection: an unnoticeable spread of colistin resistance in Brazil? Clinics 72(10):642-644. <http://dx.doi. org/10.6061/clinics/2017(10)09>

Sellera F.P., Fernandes M.R., Sartori L., Carvalho M.P.N., Esposito F., Nascimento C.L., Dutra G.H.P., Mamizuka E.M., Pérez-Chaparro P.J., McCulloch J.A. \& Lincopan N. 2017. Escherichia coli carrying IncX4 plasmid-mediated $m c r-1$ and $b l a_{\text {стх-м }}$ genes in infected migratory Magellanic penguins (Spheniscus magellanicus). J. Antimicrob. Chemother. 72(4):1255-1256. <http://dx.doi.org/10.1093/jac/dkw543> <PMid:28031274> 
Terveer E.M., Nijhuis R.H.T., Crobach M.J.T., Knetsch C.W., Veldkamp K.E., Gooskens J., Kuijper E.J. \& Claas E.C.J. 2017. Prevalence of colistin resistance gene ( $m c r-1$ ) containing Enterobacteriaceae in feces of patients attending a tertiary care hospital and detection of a $m c r-1$ containing, colistin susceptible E. coli. PLoS One 12(6):e0178598. <http://dx.doi.org/10.1371/journal. pone.0178598><PMid:28575076>

Vaneechoutte M., Dijkshoorn L., Tjernberg I., Elaichouni A., Vos P., Claeys G. \& Verschraegen G. 1995. Identification of Acinetobacter genomic species by amplified ribosomal DNA restriction analysis. J. Clin. Microbiol. 33(1):1115. <http://dx.doi.org/10.1128/JCM.33.1.11-15.1995><PMid:7699025>
Wang R., Van Dorp L., Shaw L.P., Bradley P., Wang Q., Wang X., Jin L., Zhang Q., Liu Y., Rieux A., Dorai-Schneiders T., Weinert L.A., Iqbal Z., Didelot X., Wang H. \& Balloux F. 2018. The global distribution and spread of the mobilized colistin resistance gene mcr-1. Nat. Commun. 9(1):1-9. <http://dx.doi. org/10.1038/s41467-018-03205-z><PMid:29563494>

Zhang X.F., Doi Y., Huang X., Li H.Y., Zhong L.L., Zeng K.J., Zhang Y.F., Patil S. \& Tian G.B. 2016. Possible transmission of $m c r$-1-harboring Escherichia coli between Companion animals and human. Emerg. Infect. Dis. 22(9):16791681. <http://dx.doi.org/10.3201/eid2209.160464><PMid:27191649> 